\title{
MODEL MANAJEMEN STRATEGIS UNTUK PENGEMBANGAN DAYA SAING FITK DAN JURUSAN MPI
}

\author{
Maman Supriatman
}

Dosen MPI FITK Syekhnurjati Cirebon

\begin{abstract}
ABSTRAK
Kebutuhan strategi pengembangan Jurusan MPI ini akan berimplikasi terutama pada pengembangan kurikulum. Disain kurikulum mencakup: scope (cakupan), dan sequence (urutan). Ruang lingkup pengembangan kurikulum pada Jurusan MPI harus mencakup kebutuhan pengembangan managerial-skills dan technical-skills secara proporsional. Hal ini berkaitan dengan penyusunan skenario organisasi, yakni pengembangan serangkaian asumsi tentang lingkungan tugas. Asumsinya, para lulusan Jurusan MPI nantinya akan menempuh jenjang karier tenaga kependidikan secara berjenjang dan bertahap, mulai level manajerial bawah, kemudian level tengah dan berakhir pada level manajerial atas.Kualifikasi tenaga kependidikan yang dijelaskan dalam UU RI Nomor 20/2003 tentang SISDIKNAS sebagaimana telah dikemukakan, sekaligus mencerminkan scope dan sequence kurikulum Jurusan MPI, yaitu rumpun atau disiplin ilmu pendidikan yang fokus pada kajian: pengawasan, pengembangan, pengelolaan, pelaksana administrasi dan tenaga teknis. Khusus untuk kompetensi pengembangan, harus difahami dalam konteks fungsi FITK dalam rangka pengertian pendidikan Islam secara luas, yang antara lain mencakup kajian pengembangan tentang teori-teori pendidikan Islam, sebagaimana ditegaskan oleh Ahmad Tafsir di atas. Fungsi ini pernah dikembangkan pada Jurusan Kependidikan Islam (KI). Kompetensi demikian paralel dengan kualifikasi tenaga pengembang, pengawas maupun pengelola satuan pendidikan sebagaimana dimasudkan di atas. Karena itu, beberapa PTI mengkonversi Jurusan KI menjadi Jurusan MPI. Implikasinya terhadap perumusan kurikulum Jurusan MPI, maka cakupan kurikulumnya harus juga berorientasi pada penguatan pemikiran bagi pengembangan teori serta konsep-konsep pendidikan Islam.
\end{abstract}

Kata Kunci: Model, Manajemen Strategis, Daya Saing, FITK, MPI, Formulasi Grandstrategy, Formulasi Unit Bisnis/Fakultas, dan Formulasi Fungsional/Jurusan.

\section{A. Pendahuluan}

Lembaga pendidikan yang baik adalah lembaga pendidikan yang berdaya saing tinggi, dan lembaga pendidikan yang berdaya saing tinggi sudah pasti adalah lembaga pendidikan yang menerapkan prinsip-prinsip manajemen pendidikan. Sedangkan lembaga pendidikan yang menerapkan prinsip-prinsip manajemen pendidikan sudah pasti Islami, karena penerapan prinsip-prinsip manajemen yang sudah terbukti berhasil, merupakan bagian dari Sunnatullah dalam bidang pendidikan, dan itu merupakan bagian dari prinsipprinsip Islam tentang pendidikan. Karena itu, manajemen Pendidikan Tinggi Islam (PTI) perlu menerapkan prinsip-prinsip manajemen yang sudah teruji keberhasilannya. Dengan demikian, bila sebagian besar PTI belum menunjukkan kinerja serta daya saing yang baik, maka dipastikan penyebab utamanya adalah karena belum menerapkan teori dan prinsip-prinsip manajemen pendidikan yang sudah terbukti keandalannya.

Di sisi lain, organisasi yang memiliki daya saing adalah organisasi yang 
memiliki orang-orang yang kompeten. Pendidikan Tinggi yang memiliki daya saing adalah Pendidikan Tinggi yang memiliki orang-orang yang kompeten. Untuk menghasilkan orang-orang yang kompeten, diperlukan lembaga yang kompeten. Fakultas Ilmu Tarbiyah dan Keguruan (FITK) sebagai satu-satunya Lembaga Pendidikan Tenaga Kependidikan (LPTK) di lingkungan PTI harus dikembangkan untuk menghasilkan orangorang yang kompeten dalam penyelenggaraan PTI.

Saat ini setiap organisasi menghadapi lingkungan dimana perubahan terjadi pada tingkat yang belum pernah terjadi sebelumnya. Inovasi terus menerus dalam bidang teknologi informasi bersama dengan globalisasi telah menciptakan perubahan lingkungan dengan tingkat turbulensi yang semakin tinggi. Akibatnya, banyak pedoman dan prinsip manajemen yang diciptakan untuk suatu organisasi yang stabil dan dapat diramalkan, tidak lagi relevan.

Karena itu, organisasi yang sukses pada abad 21 ini harus mampu belajar dan merespons dengan cepat dan tepat. Maka yang dibutuhkan setiap organisasi saat ini adalah manajer yang dapat secara efektif menantang kebijakan konvensional, mengelola basis pengetahuan organisasi untuk membuat perubahan yang diperlukan. Inilah tren baru dalam teori organisasi, yaitu suatu organisasi yang telah mengembangkan kapasitasnya untuk terus menerus belajar, beradaptasi dan berubah, yakni organisasi pembelajar (learning organization) sebagai antitesis bagi organisasi tradisional (Robbins \& Coulter, 2007).

Teori manajemen yang fokus pada perumusan strategi yang bertolak dari hasil analisis lingkungan internal dan eksternal strategis adalah teori manajemen strategis. Meskipun manajemen strategis itu berasal dari dunia industri dan bisnis yang profitoriented, namun sesuai dengan prinsip universalitas manajemen dari Robbins \& Coulter (2007), maka langkah-langkah manajerial serta prinsip-prinsipnya pada setiap tahapan manajemen, dapat digunakan oleh setiap jenis dan ukuran organisasi, termasuk dalam lingkungan organisasi yang sifatnya non-profit oriented (Rowe et all, 1989), seperti dalam manajemen institusi pendidikan.

Tulisan ini akan berupaya untuk menjawab pertanyaan-pertanyaan pokok berikut: (1) Mengapa manajemen PTI membutuhkan sebuah model pengembangan? (2) Bagaimana prinsipprinsip dan tahapan dalam manajemen strategis dapat dijadikan model bagi strategi pengembangan daya saing PTI? (3) Bagaimanakah tahapan formulasi strategi dalam model manajemen strategis dapat diterapkan pada seluruh tahapan manajemen PTI. Pertanyaan ketiga ini mencakup tahapan formulasi strategi pada ketiga level manajemen PTI, yaitu: a) Formulasi strategi pada level Institut; b) Formulasi strategi pada level Fakultas; dan c) Formulasi strategi pada level Jurusan. Out-put yang diharapkan dari seluruh tahapan formulasi strategi itu adalah peningkatan daya saing PTI.

\section{B. Urgensi Model bagi Pengembangan Pendidikan Tinggi Islam (PTI)}

Dalam perspektif manajemen pendidikan, tugas utama pendidikan adalah mengarahkan dan mengendalikan perubahan. Mengendalikan perubahan berarti merencanakan perubahan. Karena itu, diperlukan model perencanaan perubahan. Dalam kondisi belum ditemukan best practice dalam manajemen PTI, khususnya dalam strategi pengembangan Jurusan Manajemen Pendidikan Islam (MPI) di lingkungan Fakultas Ilmu Tarbiyah dan Keguruan (FITK), maka dibutuhkan sebuah model pengembangan berbasis manajemen. Jenis model yang dibutuhkan adalah Developmental/Exploratory Model, atau model pengembangan yang bersifat eksploratoris, bukan Best-practice Model, 
atau model yang diangkat dan berasal dari best-practice dalam manajemen PTI.

Perkembangan dalam manajemen pendidikan tinggi telah memunculkan sejumlah inovasi; bahwa sebagai organisasi terbuka, penyelenggaraan pendidikan tinggi tidak boleh berhenti berinovasi. Manajemen pendidikan tinggi harus selalu mencari titik keseimbangan baru antara kecenderungan mempertahankan stabilitas dengan kebutuhan untuk menyesuaikan diri dengan tuntutan perubahan lingkungan strategis. Dalam kontek manajemen PTI, kebutuhan untuk memelihara titik keseimbangan itu muncul dari tradisi, karakteristik dan posisinya yang khas yang dibentuk oleh sepanjang sejarah perkembangnnya, dengan berbagai tuntutan baru yang muncul seiring perubahan lingkungan.

Dalam praktik manajemen pendidikan tinggi nasional, banyak kebijakan dalam manajemen pendidikan tinggi di Indonesia, berasal dari Developmental/Explortory Model, yang kemudian diimplementasikan dalam bentuk program pengembangan pendidikan tinggi, misalnya: RAISE, Wolrd-Class University, Corporate University, Core Competency, Strategi Keunggulan Bersaing dan Peningkatan Daya Saing, Learning Organization, Performance-Based Management, Strategic Management, Pengembangan Budaya Organisasi, Manajemen Mutu, Manajemen Pemasaran Jasa Pendidikan, Manajemen Perubahan, Manajemen Pengetahuan, dan Redesain Pendidikan Profesioal Guru.

Di sisi lain, terdapat beberapa kasus inovasi yang diangkat dalam penelitian untuk Disertasi yang berasal dari Bestpractice Model, dan karenanya dapat dijadikan bahan masukan bagi formulasi model strategi pengembangan yang berpeluang untuk diimplementasikan dalam manajemen PTI, antara lain: (1) Implementasi Strategic Management dalam Manajemen Pendidikan Tinggi (Ismaun, 1999); (2) Manajemen Pengembangan Dosen sebagai Penjamin Mutu dalam
Manajemen Pendidikan Tinggi (Kusumastuti, 2001); (3) Implementasi Knowledge Management dalam Konteks Organisasi Pembelajar (Tjakraatmadja \& D.C. Lantu, 2006); (4) Manajemen Pengembangan Mutu Dosen dan Implementasi Learning Organization Berbasis Karakteristik PTI (Sholihah, 2006); dan (5) Penjaminan Mutu Pendidikan Tinggi dan Audit Kinerja Dosen di Lingkungan PTIS (Rahminawati, 2007).

Sebuah model adalah representasi simbolik dari suatu benda, proses, sistem atau gagasan. Aubrey Fisher (2012) berpendapat bahwa model adalah sebuah analogi yang mengabstraksikan dan memilih bagian dari keseluruhan, unsur, sifat atau komponen yang penting dari fenomena yang dijadikan model. Sedangkan teori adalah abstraksi dari realitas, terdiri atas asumsi, proposisi dan aksioma-aksioma dasar yang saling berkaitan. Dengan demikian, hubungan antara model dengan teori, bahwa model membantu merumuskan suatu teori dan menyarankan hubungan. Oleh karena model memilih unsur-unsur tertentu, maka suatu model mengimplikasikan penilaian atas relevansi, yang pada gilirannya mengimplikasikan suatu teori mengenai fenomena yang diteorikan. Karenanya, suatu model berfungsi sebagai basis bagi teori yang lebih kompleks, atau alat untuk menjelaskan teori dan menyarankan caracara baru untuk memperbaiki konsepkonsep.

\section{Teori Manajemen Strategis sebagai Acuan Model Strategi Pengembangan PTI}

\section{Konsep Manajemen Strategis}

Manajemen strategis adalah manajemen yang fokus pada proses penetapan tujuan organisasi, pengembangan kebijakan, dan perencanaan untuk mencapai sasaran, serta mengalokasikan sumber daya untuk menerapkan kebijakan dan merencanakan 
pencapaian tujuan organisasi (Fred R. David, 2004). Ketchen (2009) mendefinisikan manajemen strategis sebagai analisis, keputusan dan aksi untuk menciptakan dan mempertahankan keunggulan kompetitif.

Dua definisi di atas berkaitan dengan:

a. Bagaimana menganalisis sasaran strategis (visi, misi dan tujuan organisasi) serta kondisi internal dan eksternal yang dihadapi organisasi. Selanjutnya organisasi harus mengambil keputusan strategis guna menjawab dua pertanyaan utama: (1) kualitas produk atau out-put seperti apa yang ingin dihasilkan organisasi; bagaimana organisasi harus bersaing; dan

b. Bagaimana organisasi mampu mengalahkan organisasi lainnya. Manajer perlu menentukan bagaimana organisasi bisa menciptakan keunggulan kompetitif yang tidak hanya unik dan berharga, tetapi juga sulit ditiru sehingga bisa bertahan lama. Keunggulan kompetitif yang mampu bertahan lama biasanya diperoleh dengan melakukan aktivitas berbeda dengan apa yang dilakukan pesaing, atau melakukan aktivitas yang sama dengan cara yang berbeda.

\section{Tahapan Manajemen Strategis}

Karena manajemen strategis didefinisikan sebagai suatu proses yang berorientasi masa depan yang memungkinkan organisasi untuk membuat keputusan hari ini dalam memposisikan diri bagi kesuksesan pada masa mendatang, maka langkah pertama yang harus dilakukan adalah pemantauan terhadap lingkungan organisasi, baik internal maupun eksternal. Berdasarkan hasil pemindaian lingkungan itu baru dapat dilakukan formulasi atau perumusan strategi, kemudian implementasi strategi, dan terakhir kemajuan organisasi terhadap strategi dievaluasi.

Sementara di masa lalu perhatian lebih diberikan pada tahap perencanaan, saat ini setiap organisasi harus menyadari sifat kritis dari aspek pelaksanaan. Rencana terbaik akan tidak berarti jika pelaksanaannya cacat.

Komponen terakhir dari manajemen strategis adalah evaluasi dan monitoring kemajuan organisasi ke arah sasaran strategisnya. Organisasi2 yang merasa aman setelah rencana diimplementasikan tanpa perhatian yang memadai terhadap pemantauan kinerja organisasi dalam mencapai sasaran2 strategisnya, akan menemukan dirinya mengalami kegagalan (Alan J. Rowe, et.all, 1989).

Pemahaman yang benar tentang konsep strategi akan berguna untuk memahami inti sasaran manajemen strategis. Definisi strategi pertama kali digunakan oleh Chandler (1962), bahwa strategi adalah tujuan jangka panjang dari suatu organisasi serta alokasi dan pendayagunaan seluruh sumber daya untuk mencapai tujuan tersebut. Dalam perkembangannya konsep mengenai strategi mengalami perluasan hingga mencakup penggunaan pada berbagai jenis dan ukuran organisasi, baik yang berorientasi profit maupun non-profit. Namun ada dua konsep kunci yang tidak berubah dalam strategi, yaitu: (1) Distintive Competence, yakni tindakan yang dilakukan agar organisasi lebih baik dibanding pesaingnya, yang meliputi keahlian tenaga kerja dan kompetensi SDM; dan (2) Competitive Advantage, yakni keunggulan bersaing disebabkan oleh pilihan strategi yang dilakukan organisasi untuk merebut peluang eksternal.

\section{a. Analisis Lingkungan bagi Penetapan Tujuan Spesifik Organisasi}

Teknik yang banyak digunakan adalah analisis SWOT (Strenghts, Weaknesses, Opportunities, Threats); 
kekuatan dan kelemahan internal serta peluang dan ancaman eksternal. Teknik ini pertama kali dikembangkan oleh Albert Humprey pada dasawarsa 60-70an. Analisis SWOT dapat diterapkan pada berbagai jenis dan ukuran organisasi dengan memilah berbagai hal yang mempengaruhi keempat faktornya, kemudian menerapkannya dalam gambar matrix SWOT. Adapun aplikasinya adalah: (1) Bagaimana kekuatan internal mengambil keuntungan dari peluang eksternal; (2) (3) Bagaimana mengatasi kelemahan yang dapat mencegah keuntungan; Bagaimana kekuatan internal digunakan untuk menghadapi ancaman; dan (4) Bagaiama cara mengatasi kelemahan yang mampu membuat ancaman menjadi peluang.

Manajemen strategis memberi perhatian yang sama pada analisis lingkungan internal dan eksternal. Organisasi yang merasa nyaman hanya dengan melakukan pemindaian lingkungan internal, akan kehilangan separo peluang untuk membuat keputusan yang efektif bagi organisasinya. Beberapa elemen yang biasa digunakan untuk pemindaian lingkungan eksternal meliputi: organisasi sebagai suatu keseluruhan (termasuk tren yang berdampak pada organisasi), serta tren sosial pada empat bidang utama: ekonomi, teknologi, tren politik-hukum, dan sosial budaya. Data dari pemantauan lingkungan ini kemudian digunakan untuk membuat rencana strategis bagi organisasi. Sebuah pepatah lama mengatakan: "gagal dalam merencanakan sama dengan merencanakan untuk gagal". Jika sebuah organisasi tidak merencanakan arahnya, maka organisasi itu tidak akan bisa mengambil kendali atas masa depannya.

\section{b. Formulasi Strategi}

Formulasi strategi merupakan proses perumusan langkah-langkah ke depan guna mengembangkan visi dan misi organisasi, menetapkan tujuan strategis serta merancang strategi untuk mencapai tujuan tersebut dalam rangka mencapai customer values terbaik. Morton (1996) menggambarkan proses formulasi strategi dimulai dengan "identify the organization's current mission, goals and strategies". Kemudian melakukan analisis kekuatan dan kelemahan internal serta analisis peluang dan ancaman eksternal. Berdasarkan hasil analisis lingkungan itu barulah dapat dirumuskan strategi. Dalam suatu organisasi besar terdapat tiga tingkatan strategi, yaitu strategi korporasi, strategi bisnis unit, dan strategi fungsional (Peter Wright, Mark J. Kroll \& John Parnell, 1996).

\section{1) Strategi Korporasi: Grand Strategy Organisasi}

Strategi ini berkaitan dengan perumusan arah organisasi secara keseluruhan, dimaksudkan untuk mengarahkan organisasi pada tiga pilihan strategi pengembangan, yaitu: strategi pertumbuhan (growth), strategi stabilitas (stability) dan strategi pengurangan (rethenchment). Ketiga orientasi strategi ini dikenal sebagai Grand Strategy.

a) Strategi Pertumbuhan. Terdiri atas strategi konsentrasi dan srategi diversifikasi. Strategi konsentrasi meliputi: pertumbuhan vertikal dan horizontal. Pertumbuhan vertikal bisa dicapai secara internal dengan cara memperluas bidang operasi, atau secara eksternal melalui akuisisi. Sedangkan strategi diversifikasi dipilih ketika pertumbuhan tidak menunjukkan kemajuan, serta tidak ada lagi peluang untuk tumbuh dalam bidang aslinya. Ada dua jenis strategi diversifikasi: konsentrik dan konglomerasi. Strategi konsentrik dipilih ketika organisasi akan menambah produk baru yang masih terkait dengan produk aslinya; sedangkan strategi konglomerasi dipilih bila organisasi ingin menambah produk atau pasar 
baru yang tidak terkait dengan produk lama.

b) Strategi Stabilitas. Strategi ini dipilih bila organisasi akan tetap melanjutkan aktivitasnya tanpa perubahan arah yang signifikan. Terdiri atas: Pause, No-Change Strategy, dan Profit Strategy. Strategi Pause ditempuh bila organisaai memilih untuk istirahat sambil menunggu keputusan untuk melanjukan ke Strategi Pertumbuhan atau Pengurangan. Strategi Tidak Ada Perubahan adalah keputusan untuk tidak melakukan sesuatu yang baru sampai periode waktu tertentu. Sedangkan Strategi Laba adalah keputusan untuk tidak melakukan sesuatu yang baru dalam satu situasi yang buruk, dan bertindak seolah2 masalah yang dihadapi hanya bersifat sementara.

c) Strategi Pengurangan. Strategi ini digunakan ketika organisaai berada pada posisi yang lemah pada beberapa atau semua lini yang mengakibatkan performa organisasi yang rendah. Beberapa jenis strategi yang dapat dipilih adalah: (1) Strategi Putar Haluan, menekankan pada perbaikan efisiensi operasional; digunakan bila masalah yang dihadapi sudah menjalar tetapi belum kritis; (2) Strategi Tawanan, digunakan ketika organisasi memilih untuk mengurangi aktivitas fungsionalnya; (3) Strategi Menjual, digunakan bila manajemen menilai bahwa dengan menjual aset, organisasi masih bisa memperoleh values yang baik; (4) Strategi Kepailitan adalah strategi terakhir berupa penyerahan seluruh aset ke Pengadilan sebagai usaha penyelesaian kewajibannya.

d) Strategi Kombinasi. Strategi kombinasi digunakan apabila: (a) Grand Strategy organisasi difokuskan pada berbagai strategi besar secara sadar (strategi stabilitas, pertumbuhan dan pengurangan digunakan secara simultan); dan (b) Organisasi merencanakan untuk menggunakan strategi besar yang berbeda di masa depan. Meski penerapan strategi kombinasi ini tidak mudah, namun sangat tepat digunakan bagi organisasi yang menghadapi perubahan lingkungan dengan tingkat kecepatan tidak sama, dan karenanya produk yang dihasilkan berada pada tingkatan daur hidup produk yang berbeda.

\section{2) Strategi Bisnis Unit (SBU): Strategi Bersaing}

SBU pertama kali diperkenalkan pada tahun 1979 oleh Mc. Kensey and Co dalam kerjasamanya dengan General Electric. Definisi generik $S B U$ adalah suatu cara mengelola organisasi agar setiap unit menghasilkan sejumlah produk atau jasa yang ditujukan pada segmen sasaran tertentu dalam iklim persaingan dengan sejumlah pesaing. Bisnis secara umum berarti seluruh kegiatan yang diorganisasikan oleh semua orang yang terlibat dalam rangka memperbaiki standar kualitas. Sedangkan strategi didefinisikan sebagai alat untuk mencapai tujuan jangka panjang (Fred R. David dalam Husein Umar, 2007).

Strategi merupakan suatu tindakan yang incremental (senantiasa meningkat dan terus menerus), serta dilakukan berdasarkan sudut pandang tentang apa 
yang diharapkan di masa depan. Dengan demikian, strategi hampir selalu dimulai dari apa yang dapat terjadi, dan bukan dimulai dari apa yang terjadi.

Berdasarkan pemahaman demikian, maka dapat didefinisikan bahwa Strategic Business Unit (SBU) adalah strategi untuk menciptakan suatu unit yang menghasilkan produk atau jasa yang fokus pada satu kelompok pelanggan tertentu (N.A. Orcullo, 2007). Karena itu strategi bisnis unit sering juga disebut sebagai strategi bersaing, yakni strategi yang berfokus pada peningkatan posisi bersaing organisasi. Untuk menjalankan strategi bisnis unit biasanya dipimpin oleh seorang manajer yang memimpin sebuah unit otonom.

Ada dua jenis $S B U$, yakni Strategi Kompetitif dan Strategi Kooperatif. Yang paling banyak digunakan adalah Strategi Kompetitif. Konsep persaingan yang populer diperkenalkan oleh pakar ekonomi mikro, M.E. Porter, yakni konsep Strategi Generik, sebuah strategi bersaing untuk mengungguli kompetitor. Porter menawarkan tiga tipe strategi generik, yaitu: Cost Leadership Strategy, Differentiation Strategy, dan Focus Strategy. Ketiga jenis strategi ini saling berkaitan dan dalam implementasinya dapat digabungkan:

a) Fokus biaya adalah strategi bersaing yang fokus kepada customer pada segmen geografis tertentu dengan harga seefisien mungkin. Strategi ini didasarkan atas asumsi bahwa organiasi yang mengkonsentrasikan pelayanan pada target-target strategis yang sempit secara lebih efisien, akan memiliki daya saing yang kuat.

b) Fokus pada diferensiasi berarti organisasi harus mencari diferensiasi pada segmen sasarannya. Pemilihan strategi ini didasarkan pada asumsi bahwa organisasi yang memfokuskan pelayanan pada segmen sasarannya yang lebih sempit, akan lebih efektif dibandingkan kompetitotnya.
Karena itu, $S B U$ memiliki lima ciri pokok, yaitu: (1) Eksternal focus, bahwa pengorganisasian strategi mengacu pada permasalahan yang timbul karena faktor eksternal; (2) Identifiable Competitor, yakni $S B U$ yang dirancang demikian rupa sehingga kompetitor teridentifikasi; (3) Autonomous Profit Center, yakni beroperasi sebagai suatu bisnis serta sasarannya sendiri dan dipimpin oleh seorang manajer; (4) Distinct Marketing Strategy, yakni memiliki strategi pemasaran sendiri yang berbeda dengan unit bisnis lainnya; dan (5) Separate Accounting, yakni $S B U$ yang bersaing sebagai suatu unit yang bersifat otonom sehingga harus memiliki sistem pembukuan sendiri yang terpisah dari unit lainnya (Husein Umar, 2005).

Penjabaran dari strategi adalah taktik, yakni penjabaran operasional jangka pendek dalam rangka menerapkan strategi. Taktik bersaing adalah sebuah rencana operasional khusus yang menjelaskan bagaimana, kapan dan dimana sebuah strategi diimplementasikan. Beberapa taktik bersaing yang banyak digunakan adalah taktik waktu, taktik menyerang dan taktik defensif.

\section{3) Strategi Fungsional}

Strategi fungsional adalah pendekatan terhadap area fungsional dalam rangka mencapai grand strategy organisasi dan strategi bersaing pada bisnis unit dengan memaksimalkan produktivitas sumberdaya yang dimiliki organisasi. Strategi ini menitik beratkan pada pengembangan dan pemeliharaan suatu kompetensi khusus (distinctive competency) untuk menghasilkan keunggulan bersaing.

Terdapat beberapa jenis strategi fungsional, yaitu strategi: produksi, promosi, pemasaran, keuangan, manajemen SDM, litbang, teknologi informasi, dan strategi-strategi fungsional yang berkaitan dengan fihak eksternal seperti: suplier, konsultan, dan agen. Kriteria pemilihan strategi yang direkomendasikan ditetapkan berdasarkan hasil analisis lingkungan 
SWOT. Pertimbangan lain adalah kemampuan setiap alternatif strategi dalam memenuhi tujuan dengan sumber daya paling efisien dan dengan efek samping paling minimal.

Ada dua hal berkaitan dengan pemilihan strategi: Pertama, penyusunan skenario organisasi, yakni pengembangan serangkaian asumsi tentang lingkungan tugas. Kedua, proses penetapan pilihan strategi, yakni evaluasi terhadap berbagai alternatif strategi dalam hal kemampuannya memenuhi empat kriteria berikut: a) Mutually Exlusivity, pelaksanaan suatu alternatif strategi terlepas dari strategi yang lain; b) Success, layak dan berpeluang besar untuk berhasil; c) Completeness, strategi yang dipilih harus mampu memperhitungkan seluruh faktor strategis; dan d) Internal Consistency, masuk akal dan tidak bertentangan dengan tujuan dan kebijakan.

\section{c. Pengembangan Kebijakan}

Akhir dari perumusan strategi adalah pengembangan kebijakan yang berfungsi sebagai pedoman dasar implementasi strategi bagi seluruh tingkatan organisasi. Pengembangan kebijakan ini sangat penting terutama bagi organisasi dengan skala besar dimana cakupan geografis dan cabang2nya tersebar luas.

Inti kebijakan berisi faktor2 penting keberhasilan (Critical Succsess Factors, $C S F$ ), yakni standar kriteria atau tolok ukur keberhasilan atas penerapan strategi. Berbagai hasil penelitian membuktikan bahwa organisasi dengan $C S F$ yang jelas, akan memenangkan persaingan. $C S F$ itu berbeda antara satu organisasi dengan organisasi lainnya, sesuai dengan hasil analisis atau pemindaian lingkungan serta strategi yang digunakan.

\section{Formulasi \\ Strategi \\ Pengembangan Daya Saing FITK dan Jurusan MPI}

Teori manajemen strategis memberikan kerangka model yang bisa digunakan dalam seluruh tingkatan manajemen PTI. Seperti sudah dikemukakan, manajemen strategis mencakup tiga langkah utama, yaitu: formulasi strategi, implementasi strategi dan monitoring serta evaluasi strategi. Untuk menyusun formulasi strategi, diperlukan pemindaian lingkungan terkini, dan teknik yang saat ini masih banyak digunakan adalah analisis SWOT. Hasil analisis SWOT dikompilasi dalam bentuk matrix SWOT sebagai titik tolak untuk menetapkan pilihan strategi yang akan digunakan.

Tiga tingkatan strategi dalam manajemen strategis, paralel dengan tingkatan manajemen PTI. Misalnya, dalam kasus IAIN Syekh Nurjati Cirebon, GrandStrategy paralel dengan formulasi strategi pada tingkat Institut; Strategi Bisnis Unit paralel dengan strategi Fakultas; dan strategi fungsional paralel dengan strategi Jurusan.

\section{Formulasi Strategi pada Tingkat Institut}

Seperti dijelaskan oleh Morton (1996), formulasi strategi merupakan proses perumusan langkah-langkah ke depan guna mengembangkan visi dan misi organisasi, menetapkan tujuan strategis serta merancang strategi untuk mencapai tujuan tersebut. Karena itu, formulasi Grand-Strategy dimulai dengan "identify the organization's current mission, goals and strategies". Hasil akhir dari strategi pengembangan pada tingkat korporasi atau dalam hal ini pada tingkat Institut, adalah Rencana Strategis (Renstra) Pengembangan Institut. Untuk itu diperlukan analisis tentang kekuatan dan kelemahan internal serta peluang dan ancaman eksternal pada tiap faktor kunci keberhasilan $(C S F)$. $C S F$ itu dalam konteks manajemen pendidikan tinggi, termasuk PTI, bisa dirumuskan sebagai bidang atau aspek manajemen penyelenggaraan pendidikan tinggi, yaitu bidang-bidang: kurikulum dan pembelajaran, kemahasiswaan, ketenagaan, keuangan, sarana, prasarana dan fasilitas, penelitian dan pengabdian masyarakat, 
penjaminan mutu, kerja sama dan hubungan masyarakat.

Mengingat keterbatasan ruangan, tulisan ini tidak mungkin menyajikan hasil analisis SWOT pada tiap CSF. Namun berdasarkan pengalaman dan pengamatan terlibat, kiranya dapat diidentifikasi pilihan strategi yang layak dipertimbangkan. Seperti sudah dikemukakan, terdapat empat pilihan strategi pada tingkat korporasi, yaitu strategi pertumbuhan, stabilitas, pengurangan dan strategi kombinasi.

Berdasarkan asumsi untuk kasus IAIN Syekh Nurjati Cirebon hasil analisis SWOT secara internal lebih dominan kekuatan $(S)$ dibandingkan dengan kelemahan $(W)$, dan secara eksternal lebih dominan peluang $(O)$ dibandingkan dengan ancaman $(T)$, maka pilihan strategi korporasi yang direkomendasikan untuk meningkatkan daya saing institusi adalah Strategi Kombinasi. Strategi ini digunakan apabila: (a) pengembangan institusi difokuskan pada berbagai strategi besar secara sadar, yakni semua strategi (stabilitas, pertumbuhan dan pengurangan) digunakan secara simultan; dan (b) bila institusi merencanakan untuk menggunakan strategi besar yang berbeda di masa depan. Dalam konteks pengembangan IAIN Syekh Nurjati Cirebon, strategi kombinasi harus digunakan apabila dalam empat atau lima tahun ke depan setelah Renstra diformulasikan, diproyeksikan untuk dikonversi pada bentuk UIN.

Selanjutnya, formulasi strategi pada tingkat Grand-Strategy Institut (dalam bentuk Renstra), akan menjadi acuan bagi perumusan strategi pada tingkat Fakultas (Strategi Bisnis Unit) dan tingkat Jurusan (Strategi Fungsional). Dengan kata lain, bila pada tingkat Institut belum memiliki dokumen Renstra yang bersifat final, maka strategi pada tingkat Fakultas dan Jurusan belum bisa dirumuskan.

\section{Formulasi Strategi pada Tingkat Fakultas}

Keparalelan antara $S B U$ dengan strategi pada tingkat Fakultas, dapat diidentifikasi dari definisi generik $S B U$, yakni suatu cara mengelola organisasi agar setiap unit menghasilkan sejumlah produk atau jasa yang ditujukan pada segmen sasaran tertentu dalam iklim persaingan dengan sejumlah pesaing. Bisnis secara umum berarti seluruh kegiatan yang diorganisasikan oleh semua orang yang terlibat dalam rangka memperbaiki standar kualitas. Sedangkan strategi didefinisikan sebagai alat untuk mencapai tujuan jangka panjang. Karena itu strategi bisnis unit disebut juga sebagai strategi bersaing, yakni strategi yang berfokus pada peningkatan posisi bersaing organisasi. Untuk menjalankan strategi bisnis unit biasanya dipimpin oleh seorang manajer yang memimpin sebuah unit otonom. Dalam konteks manajemen pendidikan tinggi, Fakultas dipimpin oleh seorang Dekan yang dalam banyak hal bersifat otonom.

Terdapat beberapa kata kunci dalam definisi generik $S B U$ yang sangat kompatibel dengan strategi pengembangan Fakultas dalam manajemen pendidikan tinggi, yaitu: a) unit yang menghasilkan produk atau jasa pada segmen sasaran tertentu dalam iklim persaingan dengan sejumlah pesaing; b) ditujukan untuk memperbaiki standar kualitas dalam rangka peningkatan daya saing institusi atau organisasi; dan c) dipimpin oleh seorang manajer dalam sebuah unit yang otonom.

Seperti diketahui, nomenklatur Fakultas di lingkungan IAIN Syekh Nurjati Cirebon telah berubah mengikuti (dan diproyeksikan untuk menjadi) UIN. Nomenklatur Fakultas Tarbiyah berubah menjadi Fakultas Ilmu Tarbiyah dan Keguruan (FITK). Secara teori, nomenklatur FITK mengimplikasikan bahwa Ilmu Tarbiyah dan Keguruan adalah dua ranah disiplin ilmu yang berbeda, meskipun masih berada dalam rumpun ilmu yang sama, yaitu rumpun kependidikan. Konsekwensi logis sebagai implikasinya adalah, FITK harus mengembangkan dua ranah disiplin ilmu kependidikan Islam atau Tarbiyah dan Keguruan dengan landasan 
epistemologi serta analisis kebutuhan lingkungan yang komprehensif.

Kata "pendidikan" dalam Islam menurut Abuddin Nata (1999) dapat ditelusuri maknanya dari tiga istilah: tarbiyah, ta'lim dan ta'dib. Kata tarbiyah dan yang serumpun dengannya diulang lebih dari 872 kali dalam al-Qur'an. Menurut al-Mu'jam, kata tarbiyah berakar pada tiga kata: (1) rabba-yarbu yang berarti bertambah dan berkembang; (2) rabbiyayarba yang berarti tumbuh dan menjadi besar; dan (3) rabba-yarubbu yang berarti: memperbaiki, menguasai, memelihara, merawat, dan menunaikan. Dari seluruh ayat tersebut, ternyata al-Qur' an menggunakan istilah tarbiyah untuk objek yang bermacam-macam, meliputi yang bersifat fisik dan nonfisik. Dengan demikian, pendidikan mencakup pemeliharaan seluruh makhluk.

Kata ta'lim yang berakar pada kata 'allama dengan berbagai akar kata yang serumpun diulang dalam al-Qur'an sebanyak lebih dari 840 kali. Istilah ini mengacu kepada pengetahuan yang diberikan kepada seseorang. Jadi lebih bersifat intelektual karena berkaitan dengan proses tranfer pengetahuan, sifatnya mengacu ke ranah kognitif. Istilah ta'dib tidak ditemukan dalam al-Qur'an, melainkan dalam Hadits, antara lain yang berbunyi: addabani Rabbi fa ahsana ta'diby.

Para ahli berbeda pendapat mengenai kata mana yang lebih mendekati makna pendidikan. Al-Nahlawy lebih cenderung menggunakan kata tarbiyah karena cakupannya yang luas. Al-Attas lebih menggunakan kata $t a$ ' dib, karena kata tarbiyah terlalu luas, mencakup pendidikan untuk hewan, sedangkan ta'dib khusus mengacu kepada manusia. Sedangkan Jalal lebih memilih kata ta'lim karena bekal pengetahuan dalam Islam dinilai memiliki kedudukan yang tinggi. Tidak heran bila Konferensi Internasional Pendidikan Islam Pertama yang diselenggarakan di Jeddah pada tahun 1977 belum berhasil merumuskan pengertian pendidikan menurut Islam. Konferensi hanya membuat kesimpulan bahwa pengertian pendidikan menurut Islam ialah keseluruhan pengertian yang terkandung dalam ketiga istilah tersebut.

Menurut Ahmad Tafsir (1992), kesulitan merumuskan definisi pendidikan Islam itu adalah karena luasnya cakupan kegiatan yang disebut pendidikan. Dalam arti luas pendidikan adalah pengembangan pribadi dalam semua aspeknya. Dalam arti yang sempit pendidikan adalah proses pembelajaran yang berlangsung di lingkungan pendidikan formal. Ilmu pendidikan Islam adalah ilmu pendidikan yang berdasarkan Islam. Isi ilmu adalah teori. Isi ilmu pendidikan Islam adalah teori-teori tentang pendidikan Islam.

Uraian panjang tentang makna generik "tarbiyah" itu dibutuhkan untuk menunjukkan bahwa maknanya sangat luas. Pendekatan yang digunakan Ahmad Tafsir karenanya menjadi relevan untuk membedah fungsi, tujuan institusional dan strategi serta arah pengembangan FITK. Melalui pembagian definisi pendidikan secara luas dan sempit (bahwa secara luas pendidikan adalah pengembangan pribadi dalam semua aspeknya dan bahwa ilmu pendidikan Islam berisi teori-teori tentang pendidikan Islam; dan definisi pendidikan secara sempit adalah proses pembelajaran yang berlangsung di lingkungan pendidikan formal), maka strategi, arah dan tujuan institusional pengembangan FITK dapat dirumuskan sebagai berikut:

a. "Ilmu Tarbiyah" paralel dengan definisi pendidikan Islam secara luas, sedangkan "Keguruan" paralel dengan definisi pendidikan Islam secara sempit.

b. Dengan demikian, FITK harus memenuhi dua fungsi sekaligus, yaitu fungsinya sebagai pemasok tenaga kependidikan (pendidikan Islam dalam arti luas); dan sebagai lembaga Keguruan, FITK harus memenuhi fungsinya sebagai pemasok tenaga pendidik dalam 
proses pembelajaran di lingkungan pendidikan formal (pendidikan Islam dalam arti sempit).

c. Guna memenuhi fungsinya sebagai pemasok Tenaga Kependidikan, maka strategi, arah pengembangan dan tujuan institusional FITK harus dipertajam sesuai dengan klasifikasi dan kualifikasi Tenaga Kependidikan, yaitu sebagai pelaksana administrasi, pengelolaan, pengembangan, pengawasan dan pelaksana teknis untuk menunjang proses pendidikan pada satuan Pendidikan (UU RI Nomor 20/2003 Bab XI Pasal 39 ayat $1)$.

d. Guna memenuhi fungsinya sebagai pemasok tenaga pendidik dalam proses pembelajaran di lingkungan pendidikan formal, maka strategi, arah pengembangan dan tujuan institusional FITK harus dipetakan berdasarkan kebutuhan tenaga pendidik di lingkungan pendidikan formal pada semua jenjang pendidikan (dasar, menengah dan tinggi).

1) Pada Jenjang Pendidikan Dasar, kebutuhan tenaga pendidik yang harus disiapkan oleh FITK adalah: Guru PAI pada SD dan SMP, Guru Bidang Studi Keagamaan pada Mts (Aqidah/Aklak, Qur'an/Hadits, Fiqih dan SKI) melalui Jurusan PAI, dan Guru untuk Bidang Studi Umum di MTs melalui Jurusan-jurusan Tadris.

2) Pada Jenjang Pendidikan Menengah, kebutuhan Tenaga Pendidik yang harus disiapkan oleh FITK adalah: Guru PAI untuk SMA, SMK dan Guru-guru Bidang Studi Keagamaan pada MA, serta semua kebutuhan Guru Bidang Studi Umum pada MA.

3) Pada Jenjang Pendidikan Tinggi, kebutuhan Tenaga Pendidik yang harus disiapkan oleh FITK adalah: Dosen PAI pada Jenjang Pendidikan Tinggi Umum, dan semua kebutuhan Dosen di lingkungan PTI semua Fakultas dan Jurusan.

e. Poin a-d yang digambarkan di atas baru mendeskripsikan salah satu dari dua fungsi utama Lembaga Pendidikan Tenaga Kependidikan (LPTK), yaitu sebagai Preparing Teacher Education, menyiapkan tenaga pendidik dan kependidikan. Fungsi LPTK lainnya adalah sebagai lembaga In-servicetraining. Dalam manajemen Tenaga Pendidik dan Kependidikan, terdapat dua gugus besar, yaitu Pengadaan dan Pengembangan. Gugus Pengadaan dikenal sebagai Preservice-training dan Gugus Pengembangan dikenal sebagai In-service-training. FITK sebagai LPTK Keagamaan seharusnya juga mengemban dua gugus tugas utamanya.

f. Implikasinya adalah, perlu dilakukan evaluasi komprehensif terhadap kapasitas FITK dalam memenuhi semua kebutuhan Tenaga Pendidik dan Kependidikan pada kedua gugus tugas serta pada seluruh Jenjang Pendidikan. Masih terdapat banyak sekali peluang pengembangan berdasarkan pemetaan kebutuhan yang 
digambarkan di atas, yaitu pada poin c, d dan e.

1) Untuk huruf c, peluang pengembangan FITK berada pada (dan menjadi wewenang) pengembangan Jurusan MPI;

2) Untuk huruf d, peluang pengembangan FITK lebih luas dan kompleks, terutama untuk pengadaan Guru pada semua Bidang Studi Umum di MTs dan MA. Idealnya, pengembangan Jurusan Tadris pada FITK harus paralel dengan kebutuhan semua Guru atau Mata Pelajaran Umum di MTs dan MA.

3) Untuk Jenjang Pendidikan Tinggi, peluang pengembangan FITK masih terbuka sangat luas. Sementara untuk memenuhi kebutuhan Dosen PAI pada Pendidikan Tinggi Umum telah dibuka Program Studi PAI pada Program Pascasarjana, maka kebutuhan Tenaga Dosen untuk semua Mata Kuliah pada semua Jurusan dan Fakultas serta Program Pendidikan (Sarjana dan Pascasarjana) untuk kebutuhan sendiri di lingkungan PTI, tampaknya masih belum diproyeksikan secara komprehensif dan integral dalam perencanaan pengembangan PTI.

4) Untuk huruf e, peluang pengembangan FITK terdapat pada semua jenjang pendidikan.

g. Untuk meningkatkan daya saing institusi melalui strategi pengembangan Fakultas, maka konsep persaingan yang populer diperkenalkan oleh pakar ekonomi mikro, M.E. Porter, yakni konsep strategi generik, sebuah strategi bersaing untuk mengungguli kompetitor, bisa digunakan. Ketiga strategi generik itu adalah: Cost Leadership Strategy, Differentiation Strategy, dan Focus Strategy. Dalam implementasinya, ketiga jenis strategi ini saling berkaitan dan dapat digabungkan. Strategi ini terutama sangat dibutuhkan untuk memenuhi kebutuhan Tenaga Dosen bagi pengembangan PTI itu sendiri, mengingat kondisi dan kualifikasi Tenaga Pendidik masih dan selalu menjadi faktor kunci bagi mutu dan daya saing setiap lembaga pendidikan.

\section{Formulasi Strategi pada Tingkat Jurusan}

Sesuai dengan judul tulisan ini, yang dimaksud adalah formulasi strategi pengembangan Jurusan Manajemen Pendidikan Islam (MPI) sebagai satusatunya Jurusan di lingkungan FITK yang mengemban tugas dan fungsi sebagai penyedia Tenaga Kependidikan. Klasifikasi dan kualifikasi Tenaga Kependidikan adalah sebagaimana yang dijelaskan dalam Bab XI Pasal 39 Ayat 1) UU RI Nomor 20/2003, yaitu: pelaksana administrasi, pengelolaan, pengembangan, pengawasan dan pelaksana teknis untuk menunjang proses pendidikan pada satuan Pendidikan. Fungsi ini harus ditegaskan sebagai corecompetency Jurusan MPI, sebagai satusatunya Jurusan yang mengemban tugas dan fungsi mengembangkan pengertian pendidikan Islam secara luas, agar tidak terjadi kerancuan dengan fungsi Jurusan lain pada FITK yang semuanya (selain Jurusan MPI) berfungsi memenuhi kebutuhan akan Tenaga Pendidik pada proses pembelajaran di lembaga pendidikan 
formal, yakni fungsi memenuhi pengertian pendidikan Islam dalam arti sempit.

Bila dicermati lebih seksama, klasifikasi dan kualifikasi Tenaga Kependidikan sebagaimana dimaksudkan UU RI Nomor 20/2003 tersebut, dapat dikelompokkan pada dua gugus kompetensi, yaitu gugus kompetensi teknis (hard-skills) dan gugus kompetensi intelektual (soft-skill). Gugus pertama meliputi kualifikasi tenaga pelaksana administrasi dan pelaksana teknis. Gugus kedua meliputi kualifikasi tenaga pengelolaan, pengembangan dan pengawasan. Dengan kata lain, yang pertama lebih membutuhkan technicalskills, sedangkan yang kedua lebih membutuhkan managerial-skills. Dalam hierarki manajemen dan kepemimpinan pendidikan, dikenal ada tiga level manajerial, yaitu: level atas, tengah dan bawah.

Semakin tinggi level manajerial semakin tinggi pula kebutuhan akan managerial-skills; sebaliknya semakin rendah level manajerial semakin tinggi kebutuhan akan technical-skills. Dengan demikian, pada level manajerial atas, kebutuhan managerial-skills adalah yang paling tinggi, pada level tengah kebutuhan pada kedua jenis skills itu seimbang, dan pada level bawah lebih tinggi kebutuhan akan technical-skills. Tenaga Kependidikan Pengembang dan Pengawas bisa dikategorikan berada pada posisi manajerial level atas, Tenaga Kependidikan Pengelola berada pada posisi manajerial tengah, dan Tenaga Kependidikan Pelaksana Administrasi dan Tenaga Teknis berada pada posisi manajerial bawah.

Beberapa jenis strategi fungsional bagi pengembangan Jurusan MPI di lingkungan FITK adalah: strategi produksi, promosi, pemasaran, keuangan, manajemen SDM, litbang, teknologi informasi, dan strategi-strategi fungsional yang berkaitan dengan fihak eksternal seperti: suplier, konsultan, dan agen. Dalam dunia pendidikan, fihak eksternal yang dimakud adalah seluruh stake-holders dan pengguna jasa (user) pendidikan. Kriteria pemilihan strategi yang direkomendasikan ditetapkan berdasarkan hasil analisis lingkungan SWOT. Pertimbangan lain adalah kemampuan setiap alternatif strategi dalam memenuhi tujuan dengan sumber daya paling efisien dan dengan efek samping paling minimal.

Karena strategi fungsional adalah strategi pengembangan Jurusan sebagai pendekatan terhadap area fungsional dalam rangka mencapai grand strategy organisasi dan strategi bersaing pada strategi tingkat unit atau fakultas dengan memaksimalkan produktivitas sumberdaya yang dimiliki, maka strategi pengembangan Jurusan haruslah menitik beratkan pada pengembangan dan pemeliharaan suatu kompetensi khusus (distinctive competency) guna menghasilkan keunggulan bersaing. Untuk itu, pengembangan kurikulum harus juga mempertimbangkan berbagai jenis strategi fungsional yang diemban oleh Jurusan MPI, yaitu konten kurikulum yang berkaitan dengan strategi promosi dan pemasaran, keuangan, manajemen SDM, litbang, teknologi informasi, dan strategistrategi fungsional yang berkaitan dengan fihak eksternal, yakni pihak-pihak berkepentingan (stake-holders) dan pengguna jasa (user) pendidikan.

Inilah core-competency kurikulum Jurusan MPI sebagai satu-satunya Jurusan di lingkungan FITK yang mengemban fungsi serta tugas sebagai penyedia tenaga kependidikan. Kompetensi-inti inilah yang merupakan keunggulan dan sekaligus membedakannya dengan Jurusan lain di lingkungan FITK yang bertugas menyediakan Tenaga Pendidik dalam berbagai disiplin ilmu. Dengan pemetaan dan penajaman kompetensi demikian, diproyeksikan out-put Jurusan MPI akan memiliki daya saing yang tinggi.

Analisis dari perspektif ekonomi pendidikan, khususnya hukum ekonomipendidikan supply and demand, 
keunggulan bersaing lulusan MPI sangat tinggi; supply tenaga kependidikan dengan spesifikasi yang dideskripsikan di atas di wilayah Cirebon khususnya, belum ada; sedangkan demand sangat tinggi, yaitu kebutuhan tenaga kependidikan pada seluruh Jenjang Pendidikan di lingkungan Kementerian Agama, serta tenaga kependidikan di lingkungan Kementerian Agama sendiri. Ketika supply rendah apalagi 0, sedangkan demand tinggi, maka daya saingnya tinggi. Kondisi ini berbanding terbalik dengan daya saing output Jurusan-jurusan pemasok tenaga Pendidik di lingkungan FITK, seperti Jurusan: PAI, Tadris-IPS, Tadris-Bahasa Inggris, dan seterusnya, dimana supply tinggi sedangkan demand rendah, sehingga daya saingnya rendah.

Selain masalah scope, kurikulum Jurusan MPI juga harus mempertimbangkan sequence atau urutan, struktur materi serta konten kurikulum dan silabus; konten technical-skills diberikan pada semester-semester awal dan tengah, sedangkan konten managerial-skills diberikan mulai semester tengah dan akhir. Hal ini terutama terkait dengan efisiensi dan efektivitas proses pembelajaran. Sedangkan efisiensi dan efektivitas adalah dua kata kunci utama dalam setiap jenis dan tingkatan manajemen. Adalah ironis bila Jurusan MPI mengabaikan dua prinsip utama dalam manajemen kurikulum dan pembelajaran.

\section{E. Kesimpulan}

Dibutuhkan Developmental Model sebagai bentuk perencanaan perubahan yang diarahkan bagi peningkatan daya saing dalam manajemen PTI, karena belum ditemukan adanya Best-practice Model yang diarahkan untuk peningkatan daya saing PTI.

Prinsip-prinsip, teori dan tahapan dalam manajemen strategis dapat dijadikan model pengembangan daya saing PTI melalui formulasi strategi pada seluruh tahapan manajemen strategis yang sepenuhnya kompatibel dengan seluruh tahapan dan level manajemen di lingkungan PTI. Pengembangan daya saing PTI dapat dirumuskan melalui formulasi strategi pada level Fakultas dan Jurusan, yang sepenuhnya paralel dengan tahapan formulasi strategi dalam manajemen strategis.

Untuk kasus pengembangan IAIN Syekh Nurjati Cirebon dengan asumsi hasil analisis lingkungan bahwa secara internal lebih dominan kekuatan daripada kelemahan, dan secara eksternal lebih dominan peluang daripada ancaman, maka strategi pengembangan yang direkomendasikan adalah strategi kombinasi, yaitu penerapan strategi pengembangan, strategi stabilitas dan strategi pengurangan diterapkan secara simultan, mengingat adanya aspirasi kuat untuk mengembangkan bentuk pendidikan tinggi dari bentuk Institut dikonversi ke bentuk tertinggi pendidikan tinggi yaitu Universitas, dari IAIN dikonversi menjadi UIN.

Untuk itu diperlukan evaluasi menyeluruh terhadap kondisi dan kinerja pada semua bisnis unit maupun fungsionalnya. Pada tingkat strategi Fakultas, dibutuhkan pemetaan yang komprehensif dan detil tentang kualifikasi dan spesifikasi kompetensi lulusan. Penajaman kompetensi diarahkan pada upaya untuk menghasilkan produk atau jasa dalam segmen sasaran tertentu pada iklim persaingan dengan sejumlah pesaing, serta untuk memperbaiki standar kualitas dalam rangka peningkatan daya saing institusi PTI. Pada tingkat Jurusan diperlukan penajaman kompetensi sesuai dengan kualifikasi sebagaimana dimaksudkan dalam standar kualifikasi Tenaga Kependidikan.

Out-put dari semua tahapan strategi pengembangan itu adalah meningkatnya daya saing PTI melalui strategi pemetaan out-put FITK serta penajaman corecompetency sebagai core-curriculum Jurusan MPI. Karena itu, implikasi paling langsung dari strategi peningkatan daya 
saing itu adalah perlunya pengembangan kurikulum dan pembelajaran Jurusan MPI. Pada dimensi kurikulum, masalah utamanya terletak pada scope dan sequence. Sedangkan pada dimensi sequence masalah utamanya terletak pada efisiensi dan efektivitas pembelajaran.

\section{RUJUKAN}

Abuddin Nata, 1997. Filsafat Pendidikan Islam. Logos Wacana Ilmu; Jakarta.

Ahmad Tafsir, 1994. Ilmu Pendidikan dalam Perspektif Islam. Remaja Rosdakarya; Bandung.

Alan J. Rowe et all, 1989. Strategic Management: A Methodological Approach. Addison-Wesley Publishing Company; California.

Bachrul Hayat \& Suhendra Yusuf, 2010. Benchmark Internasional Mutu Pendidikan. Bumi Aksara; Jakarta.

Jalaluddin \& Usman Said, 1996. Filsafat Pendidikan Islam: Konsep dan Perkembangan. PT RajaGrafindo Persada; Jakarta.

Jeanne C. Meister, 1994. Corporate Quality Universities: Lesson in Building A World-Class Work Force. ASTD; Illionis.

Linda Darling-Hamond, 2006. Powerful Teacher Education. Jossey-Bass; USA.

Michael E. Porter \& Agus Maulana, 1997. Strategi Bersaing: Teknik Menganalisis Industri dan Pesaing. Erlangga; Jakarta.
M. Zafar Iqbal, 1996. Teacher Training: The Islamic Perspective. Institute of Policy Studies and International Institute of Islamic Thought; Lahore.

Peter Wright et all, 1996. Strategic Management: Concepts and Cases. International Edition. Prentice Hal, Inc; USA.

Randall S. Schuler, 1987. Personnel and Human Resources Management. Third Edition. West Publishing Company; New York.

Samuel C. Certo et all, 1994. Strategic Management: Concepts and Application. Third Edition. Irwin; Chicago.

Stephen P. Robbins \& Mary Coulter, 2002. Manajemen. PT Intan Sejati; Klaten.

Undang-undang Republik Indonesia Nomor 20/2003 tentang Sistem Pendidikan Nasional. Fokusmedia; Bandung. 